\title{
Gegar Budaya dan Motivasi Belajar pada Mahasiswa yang Merantau di Kota Makassar
}

\author{
Cici Namira Basri \\ Program Studi Psikologi, Fakultas Psikologi, Universitas Negeri Makassar, Makassar
}

\section{Andi Ahmad Ridha}

Program Studi Magister Psikologi Profesi, Fakultas Psikologi, Universitas Airlangga, Surabaya

\begin{abstract}
Abstrak. Kesulitan beradaptasi di lingkungan baru membuat mahasiswa perantau mengalami gegar budaya yang menyebabkan motivasi belajar mahasiswa menurun. Penelitian ini bertujuan untuk mengetahui hubungan antara gegar budaya dan motivasi belajar pada mahasiswa perantau. Metode yang digunakan adalah penelitian kuantitatif. Sampel diperoleh dengan menggunakan teknik cluster random sampling. Subjek penelitian ini adalah 66 mahasiswa perantau berusia 19 - 22 tahun di Universitas X yang berasal dari luar provinsi Sulawesi Selatan yang diperoleh dari sembilan fakultas yang ada di Universitas X. Pengumpulan data dilakukan dengan menggunakan skala Gegar Budaya dan skala Motivasi Belajar. Hasil analisis data dengan uji korelasi Product Moment menunjukkan bahwa terdapat hubungan yang negatif antara gegar budaya dan motivasi belajar. Semakin tinggi gegar budaya yang dialami mahasiswa perantau maka semakin rendah motivasi belajarnya. Gegar budaya memiliki sumbangan efektif terhadap variabel motivasi belajar sebesar $5.80 \%$ dan selebihnya dipengaruhi oleh faktor lain. Hal ini menunjukkan pentingnya meminimalisir gegar budaya agar dapat meningkatkan motivasi belajar mahasiswa yang merantau.
\end{abstract}

Kata Kunci: gegar budaya, mahasiswa rantau, motivasi belajar

\section{Culture Shock and Learning Motivation among Out-Migration's Students in Makassar}

Abstract. Difficulty in adapting in new environments makes out-migration's students experience culture shock that decrease students' motivation to learn. This study aims to determine the relationship between culture shock and learning motivation in out-migration's students. The method took a quantitative research. Samples were obtained using cluster random sampling technique. The subjects of this study were 66 out-migration's students from $19-22$ years old at X University from outside the Province of South Sulawesi, obtained from nine faculties at X University. Data collection was done using Culture Shock scale and Learning Motivation scale. The results of data analysis with Product Moment correlation test shows that there is a negative relationship between culture shock and learning motivation. The higher of the culture shock experienced by out-migration's students, the lower the motivation to learn. Culture shock has an effective contribution to the learning motivation variable of $5.80 \%$ and the rest is influenced by other factors. This indicate the importance of minimizing culture shock in order to increase the learning motivation among out-migration's students.

Keywords: culture shock, motivation to learn, out-migration's students

Korespondensi: Andi Ahmad Ridha. Email: a.ahmad.ridha-2015@psikologi.unair.ac.id 
Rendahnya motivasi belajar mahasiswa merupakan masalah dilematis dalam mencapai prestasi akademik, sedangkan meraih hasil dan prestasi adalah salah satu kebutuhan individu yaitu kebutuhan akan penghargaan dan aktualisasi diri. Maslow (1943) menjelaskan bahwa tingkah laku manusia dibangkitkan dan diarahkan oleh kebutuhan-kebutuhan tertentu seperti kebutuhan fisiologis, rasa aman, rasa cinta, penghargaan, aktualisasi diri, mengetahui dan mengerti, dan kebutuhan estetik (Djamarah, 2008). Kebutuhankebutuhan tersebut yang mampu memotivasi tingkah laku individu. Bagi mahasiswa, memperoleh prestasi akademik yang baik merupakan salah satu kebutuhan akan aktualisasi diri dan motivasi yang menggerakkan perilaku individu. Vincent dan Kumar (2019) menyatakan bahwa motivasi adalah penggerak dari dalam diri yang mengarahkan perilaku. Oleh karena itu, mahasiswa dapat mencapai prestasi akademik jika memiliki motivasi belajar yang tinggi dan begitu pula sebaliknya, motivasi belajar yang rendah dapat melemahkan prestasi akademik.

Penelitian-penelitian terdahulu telah menunjukkan keterkaitan antara motivasi dan prestasi akademik. Kristini dan Mere (2010) menemukan bahwa ada hubungan yang signifikan antara motivasi belajar dan prestasi akademik pada mahasiswa, jika motivasi belajar meningkat, maka prestasi belajar juga meningkat. Penelitian yang sama juga dilakukan oleh Andriani NS (2011) pada 70 mahasiswa dengan hasil penelitian yang menyatakan bahwa ada hubungan antara motivasi belajar dan prestasi akademik. Oleh karena itu, dapat disimpulkan bahwa motivasi berperan penting dalam pencapaian prestasi akademik (Riezky \& Sitompul, 2017).

Motivasi belajar mahasiswa adalah dorongan dari dalam diri mahasiswa untuk mencapai tujuan belajar. Motivasi yang dimiliki mahasiswa akan mengarahkan perilaku dalam mencapai tujuan belajar (Ridha, 2014). Solihatin (2012) menjelaskan bahwa ciri-ciri tingginya motivasi belajar mahasiswa dapat dilihat dari: (a) rasa percaya diri akan kemampuan, (b) meraih hasil belajar di atas rata-rata, (c) tujuan belajar untuk kepuasan diri, (d) berusaha keras untuk sukses, (e) berupaya meraih hasil belajar yang tinggi, (f) berkelompok dengan teman yang pintar, (g) menyelesaikan tugas demi masa depan, (h) selalu mengerjakan tugas sendiri, dan (i) kegigihan akan memengaruhi keberhasilan. Idealnya, mahasiswa memiliki motivasi belajar yang tinggi dalam menempuh pendidikan. Namun, tidak sedikit mahasiswa memiliki motivasi belajar yang rendah seperti malas dan jenuh belajar.

Penelitian sebelumnya telah menunjukkan pentingnya motivasi belajar bagi keberhasilan akademik. Hasil penelitian Agustin (2009) yang dilakukan kepada 522 mahasiswa semester lima Universitas Pendidikan Indonesia menunjukkan bahwa mahasiswa mengalami kejenuhan belajar yang 
mencakup kelelahan emosi, kelelahan fisik, kelelahan kognitif, dan kehilangan motivasi. Berdasarkan hasil penelitian di atas, kejenuhan belajar mahasiswa dipengaruhi oleh salah satu faktor yaitu hilangnya motivasi mahasiswa untuk belajar. Tuominen-Soini dan Salmela-Aro (2014) menjelaskan bahwa kejenuhan belajar merupakan kondisi individu yang mengalami kelelahan dalam menghadapi tuntutan akademik, sehingga pencapaian akademik menurun ataupun mengalami ketidakberhasilan menyelesaikan tugas-tugas akademik. Kejenuhan belajar terjadi akibat terganggunya fungsi psikologis sosioemosional dan lemahnya faktor-faktor yang dapat menguatkan motivasi hingga membawa individu pada kondisi jenuh.

Dorongan atau motivasi individu melakukan sesuatu karena adanya teori biogenik (biogenic theories) dan teori sosiogenik (sociogenic theories). Teori biogenik menyangkut proses biologis yang lebih menekankan pada mekanisme pembawaan biologis, seperti insting dan kebutuhankebutuhan biologis, sedangkan teori sosiogenik lebih menekankan adanya pengaruh kebudayaan atau kehidupan masyarakat. Hal ini menunjukkan bahwa individu melakukan aktivitas karena didorong oleh adanya faktorfaktor kebutuhan biologis, insting dan unsurunsur kejiwaan yang lain, serta adanya pengaruh perkembangan budaya manusia atau pola-pola kebudayaan (Sardiman, 2009). Studi penelitian ulasan sistematis menemukan faktor-faktor yang memengaruhi motivasi siswa dan mahasiswa pada etnis minoritas, antara lain: (a) faktor individu, (b) faktor yang berkaitan dengan keluarga, (c) faktor yang berkaitan dengan sekolah, dan (d) faktor-faktor sosial (Isik et al., 2018).

Lingkungan sosial budaya merupakan salah satu faktor yang memengaruhi proses dan hasil belajar, namun penelitian yang berfokus pada pengaruh sosiokultural masih terbatas. Beberapa studi lebih banyak mengkaji pengaruh budaya pada motivasi kerja (Choudhary, 2013; Iguisi, 2009; Mustajbašiæ \& Husakoviæ, 2016). Salah satu penelitian telah membuktikan adanya pengaruh budaya terhadap motivasi belajar mahasiswa (Razzak, 2016). Terbatasnya penelitian mengenai budaya dikarenakan literatur yang ada khususnya dari negara-negara dengan budaya individual, mayoritas mengkaji faktor internal saja (contohnya minat, nilai, kebutuhan, dan tujuan) dan belum banyak penelitian yang melihat kaitan sosiokultural dengan motivasi (Maehr, 2008; Markus, 2016; Trumbull \& Rothstein-Fisch, 2011).

Lingkungan sosial budaya mengikat perilaku individu untuk tunduk pada normanorma sosial, susila, dan hukum yang berlaku dalam masyarakat. Individu termotivasi belajar untuk mencapai hasil belajar yang optimal, salah satunya dengan menerima, menaati, dan menyesuaikan dengan nilai-nilai budaya yang ditinggalinya (Djamarah, 2008). Penyesuaian nilai-nilai budaya yang berbeda juga harus 
dilakukan oleh mahasiswa khususnya perantau atau pendatang. Mahasiswa perantau adalah orang yang berasal dari daerah lain dengan tujuan untuk menuntut ilmu di perguruan tinggi. Mahasiswa perantau yang dimaksud dalam penelitian ini yaitu mahasiswa yang berasal dari luar provinsi Sulawesi Selatan. Salah satu faktor yang menjadi alasan mahasiswa merantau adalah keinginan untuk mendapatkan pendidikan yang berkualitas. Keberhasilan individu yang merantau terlihat dari kemampuan untuk menyesuaikan diri dengan lingkungan baru yang ditinggali (Nadlyfah \& Kustanti, 2018).

Penyesuaian diri mahasiswa perantau terhadap lingkungan baru yang memiliki budaya berbeda, mengarahkan mahasiswa untuk terdorong melakukan adaptasi budaya. Adaptasi budaya adalah sebuah proses di mana individu yang sedang berada dalam interaksi lintas budaya, berusaha merubah pola perilaku komunikatif untuk menyesuaikan diri dengan lingkungan yang baru (Cai \& Rodríguez, 1996; Maciej \& Katarzyna, 2018). Penyesuaian diri merupakan proses yang tidak sepenuhnya berjalan dengan mudah. Budaya yang baru biasanya dapat menimbulkan tekanan, karena memahami dan menerima nilai-nilai budaya lain adalah sesuatu yang sangat sulit, terlebih jika nilai-nilai budaya tersebut sangat berbeda dengan nilai-nilai budaya yang dimiliki.

Kemampuan individu dalam menyesuaikan diri dengan lingkungan baru berbeda-beda satu sama lain, ada yang tidak mengalami kesulitan meskipun dalam situasi dan kondisi yang sama dan ada pula yang mengalami kesulitan (Choirunisa \& Marheni, 2019; Mubarok, 2012). Penelitian kualitatif yang dilakukan oleh Primasari (2014) pada lima mahasiswa perantau Universitas Islam 45 Bekasi menemukan hasil bahwa mahasiswa perantau mengalami kecemasan dan ketidakpastian berada di lingkungan baru. Kecemasan disebabkan faktor perbedaan gaya hidup, bahasa, dan kebiasaan, sedangkan ketidakpastian disebabkan karena kurangnya pengetahuan akan situasi lingkungan baru dan perbedaan budaya. Mahasiswa yang tidak mampu beradaptasi dengan budaya baru akan menyebabkan terjadinya gegar budaya (culture shock), yaitu proses awal masuknya individu ke lingkungan baru yang tidak familier dengan lingkungannya sehari-hari. Oberg (1960) menyatakan bahwa gegar budaya menggambarkan keadaan psikologis yang negatif, reaksi pasif dari individu dalam menghadapi lingkungan budaya yang berbeda. Gegar budaya terjadi karena nilai budaya yang dimiliki mahasiswa berbeda dengan nilai budaya yang dimiliki masyarakat di lingkungan mahasiswa melanjutkan pendidikan (Indrianie, 2012; Rhein, 2018).

Berdasarkan studi awal kepada 30 mahasiswa perantau di Universitas $\mathrm{X}$ dengan menggunakan skala motivasi belajar menunjukkan bahwa 17 mahasiswa perantau memiliki motivasi belajar yang rendah ditandai dengan rasa malas mengembangkan dan 
mengoptimalkan keterampilan yang dimiliki, malas membaca materi sebelum dosen menjelaskan di kelas, dan tidak punya persiapan ketika dosen mengadakan ujian secara spontan. Berdasarkan hasil wawancara yang dilakukan peneliti, terdapat delapan mahasiswa yang mengalami gejala gegar budaya, ditandai dengan pola makan dan tidur yang tidak teratur, perasaan rindu dengan keluarga dan teman, dan lebih suka menyendiri atau menarik diri dari lingkungan. Subjek penelitian yang rata-rata tergabung dalam organisasi membuat subjek memilih untuk menyelesaikan tugas tambahan dari dosen setelah jam perkuliahan berlangsung karena di luar jam perkuliahan, subjek memiliki kegiatan yang cukup menyita waktu luangnya, sehingga terlihat subjek termotivasi menyelesaikan tugas kuliah dengan baik. Hasil observasi peneliti, aktivitas yang dilakukan mahasiswa perantau di luar dari jam kuliah yaitu sebagian besar memilih ke perpustakaan dan beberapa tinggal di dalam kelas melakukan diskusi sederhana dengan teman-teman. Hal tersebut dikarenakan padatnya jadwal kuliah mahasiswa tingkat awal dan rutinitas dosen memberikan tugas tambahan kepada mahasiswa setelah jam kuliah berlangsung.

Fenomena gegar budaya pada mahasiswa kebanyakan dialami oleh mahasiswa perantau dan sebagai mahasiswa baru di perguruan tinggi karena berada di antara transisi budaya yang berbeda dan dituntut untuk dapat beradaptasi dengan lingkungan dalam kondisi yang benar-benar baru. Adanya perbedaan antara lingkungan sekolah menengah dengan lingkungan perguruan tinggi dapat menimbulkan beberapa masalah bagi mahasiswa. Hal ini didukung dengan penelitian yang dilakukan oleh Niam (2009) pada tujuh mahasiswa semester dua di Universitas Muhammadiyah Surakarta yang berasal dari luar Jawa menemukan hasil bahwa terjadi gegar budaya pada mahasiswa luar Jawa dengan reaksi psikologis, yaitu sedih, rindu dengan keluarga, tidak nyaman akibat perbedaan makanan, bahasa, suhu udara antara daerah asal dan Solo, merasa tidak betah tinggal di Solo, bingung, dan merasa kesepian. Adapun kesulitan dan masalah yang dihadapi di Solo yaitu kesulitan beradaptasi, kesulitan belajar dan kuliah, kesulitan transportasi, kesulitan menyesuaikan diri dengan teman-teman baru dan masalah interaksi dengan teman, sakit, takut mengecewakan keluarga, dan masalah keuangan.

Gegar budaya menyebabkan penurunan tingkat kepercayaan diri mahasiswa lintas budaya, hal tersebut akan berdampak buruk dalam keberanian berkomunikasi dengan lingkungan sekitar seperti berkomunikasi dengan sesama penghuni indekos atau rekan kampus dan dampak ini akan memengaruhi proses perkuliahan. Mahasiswa lintas budaya akan lebih kesulitan memahami materi perkuliahan, minimnya rekan kuliah, kurangnya informasi perkuliahan, dan 
berkembangnya rasa minder yang akan mengakibatkan motivasi kuliah atau belajar mahasiswa menurun (Fariki, 2013). Setiap individu berpotensi mengalami gegar budaya sebagai akibat perpindahan dari lingkungan sekolah menengah yang lama ke lingkungan univesitas. Kebiasan-kebiasan di lingkungan yang baru dapat menyebabkan tekanan yang berakibat pada kompetensi akademik individu dan akan berdampak negatif jika gegar budaya tidak teratasi, dalam hal ini individu gagal untuk menyesuaikan diri dengan lingkungan baru dan menjadi depresi sehingga menurunkan kualitas hidupnya (Thariq \& Anshori, 2017). Stoynoff (1997) menyatakan bahwa keberhasilan psikologis yang dilakukan oleh mahasiswa perantau di lingkungan belajar yang baru berhubungan positif dengan performa akademis mahasiswa. Oleh karena itu, kegagalan penyesuaian diri mahasiswa perantau hingga menyebabkan gegar budaya akan berdampak negatif terhadap performa akademis mahasiswa dan tidak menutup kemungkinan menurunkan motivasi belajar mahasiswa. Xia (2009) menjelaskan bahwa gegar budaya dapat memengaruhi kemampuan individu dalam memecahkan masalah dan mengambil keputusan dan hal ini akan menurunkan motivasi untuk beradaptasi dengan hal-hal yang baru.

Penelitian-penelitian terdahulu telah menunjukkan adanya permasalahan akademik bagi mahasiswa perantau. Hasil penelitian Yang et al (2018) menunjukkan bahwa tujuan pribadi yang menjadi sumber motivasi dapat meminimalkan efek gegar budaya pada mahasiswa. Penelitian ini menekankan pentingnya berbaur dengan lingkungan dan menjadi aktif dalam berbagai kegiatan-kegiatan di lingkungan baru untuk menghindari stres yang disebabkan adanya perbedaan budaya bagi mahasiswa asing. Hal ini didukung oleh penelitian yang dilakukan oleh Ediana (2009) pada 30 mahasiswa perantau FISIP UAJY yang menemukan hasil bahwa sekitar 83\% mahasiswa perantau mengalami gegar budaya ditandai dengan masalah kultural, baik secara fisik maupun emosional. Sebanyak 16.67\% mahasiswa tidak mengalami gegar budaya karena berasal dari daerah sekitar Yogyakarta yang memiliki budaya tidak jauh berbeda dengan budaya Yogyakarta, sehingga disimpulkan semakin mirip budaya asal dengan budaya baru maka kemungkinan terjadi gegar budaya semakin kecil. Setengah sampel dari populasi (52\%) yang diamati mengaku terganggu motivasi belajarnya karena mengalami gegar budaya, sementara setengahnya tidak. Gangguan motivasi belajar yang dialami mahasiswa seperti malas dan bolos kuliah hingga tidak ingin ikut kuliah lagi, tidak konsentrasi belajar dan nilai Indeks Prestasi (IP) menurun. Dua orang (8\%) mengaku belum mampu beradaptasi dengan budaya baru di Yogyakarta sehingga masih mengalami gangguan kuliah dan merasa tidak nyaman hidup di Yogyakarta.

Rendahnya motivasi belajar mahasiswa karena mengalami gegar budaya juga 
ditemukan pada Universitas X di Makassar yang merupakan salah satu perguruan tinggi negeri dengan jumlah mahasiswa perantau yang cukup banyak. Berdasarkan data yang diperoleh dari divisi akademik Universitas $\mathrm{X}$, diketahui bahwa jumlah mahasiswa perantau yang meneruskan pendidikan di Universitas X tahun 2014 berjumlah 632 mahasiswa yang berasal dari berbagai daerah di Indonesia. Berdasarkan uraian permasalahan di atas, diketahui bahwa gegar budaya merupakan hal yang penting untuk dikelola dengan baik karena dapat memengaruhi motivasi belajar yang dimiliki mahasiswa, sehingga hal tersebut menarik minat peneliti untuk mengkaji lebih dalam mengenai gegar budaya dan motivasi belajar mahasiswa perantau. Hal ini menjadi penting untuk diteliti, mengingat terbatasnya referensi-referensi terbaru yang secara eksplisit mengkaji tentang gegar budaya dan motivasi belajar pada mahasiswa perantau. Oleh karena itu, penelitian ini bertujuan untuk mengetahui hubungan antara gegar budaya dengan motivasi belajar pada mahasiswa perantau. Adapun hipotesis penelitian ini yaitu terdapat hubungan negatif antara gegar budaya dan motivasi belajar pada mahasiswa perantau.

\section{Metode}

\section{Subjek penelitian}

Variabel independen pada penelitian ini adalah gegar budaya dan variabel dependen adalah motivasi belajar. Subjek penelitian ini adalah: (a) mahasiswa yang telah merantau maksimal satu tahun, (b) berasal dari luar provinsi Sulawesi Selatan, dan (c) berusia 19 22 tahun yang tersebar di sembilan fakultas pada Universitas X di kota Makassar. Responden penelitian ini terdiri dari 66 mahasiswa yang diperoleh menggunakan cluster random sampling. Cluster random sampling merupakan proses penarikan sampel yang terbagi atas kelompok-kelompok, dalam penelitian ini terbagi atas sembilan fakultas, dan dari kelompok tersebut sampel diambil secara acak. Cluster random sampling digunakan ketika populasi tersebar luas dan tidak praktis dalam mengambil sampel, dan mengambil sampel yang merepresentasikan semua elemen (Acharya et al., 2013).

\section{Instrumen penelitian}

Peneliti menggunakan instrumen berupa skala untuk mengukur motivasi belajar dan gegar budaya. Skala Motivasi Belajar disusun oleh peneliti dengan mengacu pada dua aspek motivasi belajar yang dikemukakan oleh Setiawan (2010), yaitu motivasi intrinsik dan motivasi ekstrinsik. Skala Motivasi Belajar terdiri atas 18 butir dengan Alpha Cronbach sebesar .680 dan daya diskriminasi butir berkisar antara $.312-.860$.

Selanjutnya, skala Gegar Budaya disusun dengan mengacu pada enam aspek gegar budaya yang dikemukakan oleh Oberg (1960), yaitu: (1) Ketegangan karena adanya usaha untuk beradaptasi secara psikis; (2) Perasaan kehilangan 
dan kekurangan keluarga, teman, status, dan kepemilikan; (3) Penolakan terhadap orang-orang di lingkungan baru; (4) Adanya kebingungan mengenai peran, harapan terhadap peran tersebut, nilai yang dianut, perasaan, dan identitas diri; (5) Tidak menyukai adanya perbedaan bahasa, kebiasaan, nilai atau norma, sopan santun di daerah asal dengan di daerah baru; dan (6) Perasaan tidak berdaya yang disebabkan oleh ketidakmampuan menyesuaikan diri dengan lingkungan baru (Indrianie, 2012). Skala Gegar Budaya terdiri atas 24 butir dengan Alpha Cronbach sebesar .850 dan daya diskriminasi butir berkisar antara .332 - .795.

\section{Teknik analisis data}

Data penelitian dianalisis secara statistik menggunakan analisis korelasi Product Moment untuk menguji kekuatan hubungan antara gegar budaya dan motivasi belajar pada mahasiswa yang merantau. Korelasi Product Moment digunakan untuk mengetahui kekuatan hubungan antara dua variabel (Field, 2009).

\section{Hasil}

\section{Gambaran deskriptif}

Hasil analisis deskriptif dapat dilihat pada Tabel 1, sedangkan hasil kategorisasi variabel penelitian dapat dilihat pada Tabel 2 . Nilai rerata empirik pada variabel gegar budaya dan motivasi belajar tidak jauh berbeda dengan rerata hipotetik. Berdasarkan Tabel 2, dapat diketahui bahwa mayoritas subjek berada pada kategori sedang, baik pada variabel gegar budaya maupun motivasi belajar.

\section{Tabel 1}

Hasil Analisis Deskriptif

\begin{tabular}{lcccccccc}
\hline \multirow{2}{*}{ Variabel } & \multicolumn{4}{c}{ Hipotetik } & \multicolumn{5}{c}{ Empirik } \\
\cline { 2 - 9 } & Max & Min & $M$ & $S D$ & Max & Min & $M$ & $S D$ \\
\hline Gegar Budaya & 120 & 24 & 72 & 16 & 92 & 57 & 71.64 & 8.07 \\
Motivasi Belajar & 90 & 18 & 54 & 12 & 68 & 38 & 52.74 & 5.20 \\
\hline
\end{tabular}

\section{Tabel 2}

Kategorisasi Variabel Penelitian

\begin{tabular}{ccccccc}
\hline \multirow{2}{*}{ Kategori } & \multicolumn{2}{c}{ Gegar budaya } & \multicolumn{2}{c}{ Motivasi Belajar } \\
\cline { 2 - 7 } & Interval skor & $n$ & $\%$ & Interval skor & $n$ & $\%$ \\
\hline Tinggi & $\mathrm{X}=88$ & 4 & 6.06 & $\mathrm{X}=66$ & 1 & 1.50 \\
Sedang & $56=71.64<88$ & 60 & 90.90 & $42=52.74<66$ & 63 & 95.45 \\
Rendah & $\mathrm{X}<56$ & 2 & 3.03 & $\mathrm{X}<42$ & 2 & 3.03 \\
\hline
\end{tabular}

\section{Hasil uji hipotesis}

Berdasarkan hasil uji korelasi Product Moment, diperoleh nilai korelasi sebesar $r=$ .241 dengan nilai signifikansi sebesar $p=.026$ $(p<0.05)$. Hal ini menunjukkan bahwa terdapat hubungan negatif antara gegar budaya dan motivasi belajar pada mahasiswa yang merantau. Artinya, semakin tinggi gegar budaya 
maka semakin rendah motivasi belajar pada mahasiswa yang merantau. Meskipun tingkat korelasi antarvariabel tergolong rendah. Koefisien determinasi $\left(R^{2}\right)$ sebesar .058 menunjukkan bahwa total sumbangan efektif variabel gegar budaya terhadap motivasi belajar adalah sebesar 5.80\%; sedangkan sebesar 94.20\% sisanya dipengaruhi oleh faktor-faktor lain yang tidak dilibatkan dalam penelitian ini.

\section{Pembahasan}

Hasil analisis deskriptif menunjukkan bahwa sebagian besar mahasiswa perantau di Universitas X mengalami gegar budaya yang tergolong dalam kategori sedang dan juga memiliki motivasi belajar yang tergolong sedang. Hasil uji hipotesis dengan menggunakan teknik korelasi Product Moment menunjukkan bahwa ada hubungan negatif antara gegar budaya dan motivasi belajar mahasiswa perantau di Universitas X, artinya semakin tinggi gegar budaya yang dialami mahasiswa perantau, maka motivasi belajarnya semakin rendah.

Yang et al. (2018) menjelaskan bahwa gegar budaya adalah faktor utama yang memengaruhi pencapaian akademik individu. Individu harus belajar beradaptasi dengan beragam hal yang tidak sesuai dengan budayanya. Hal ini menekankan bahwa ketika motivasi untuk belajar tinggi, maka hal tersebut menjadi kekuatan bagi individu agar dapat melewati fase-fase gegar budaya dan bertahan dengan kondisi yang tidak menyenangkan. Sebaliknya, ketika motivasi untuk belajar rendah, maka individu akan mengalami gegar budaya yang tinggi, sehingga dapat melemahkan pencapaian akademiknya. Zhou et al. (2008) menambahkan bahwa gegar budaya menggambarkan penderitaan yang dirasakan individu ketika berada di budaya baru. Hal ini dipicu oleh pengalaman dan pola interaksi sosial yang berbeda. Gegar budaya juga dikatakan sebagai ekspresi dari kesulitan emosional dan fisik dalam situasi atau budaya baru, sehingga mengakibatkan individu mengalami kerusakan mental atau mental yang tidak sehat.

Gegar budaya tidak hanya terjadi di budaya baru, melainkan terjadi pada semua jenis situasi baru, pekerjaan, hubungan dan lain-lain yang membutuhkan penyesuaian dan membangun identitas baru Zhou et al. (2008). Keberhasilan individu yang merantau terlihat dari kemampuan untuk menyesuaikan diri dengan lingkungan baru yang ditinggali, tetapi budaya yang baru biasanya dapat menimbulkan tekanan, karena memahami dan menerima nilai-nilai budaya lain adalah sesuatu yang sangat sulit, terlebih jika nilai-nilai budaya tersebut sangat berbeda dengan nilai-nilai budaya yang dimiliki (Wijanarko \& Syafiq, 2013). Hal ini menunjukkan bahwa gegar budaya dapat menjadi momok yang menakutkan jika individu tidak mampu menyesuaikan diri dengan baik. 
Berdasarkan data penelitian yang diperoleh peneliti, rata-rata mahasiswa perantau berasal dari daerah yang tidak tertinggal jauh dari modernisasi sehingga kehidupan kota sudah dirasakan subjek dan tidak membuat subjek susah untuk memahami gaya hidup di kota Makassar. Selain itu, terdapat subjek yang berasal dari daerah Sulawesi seperti Sulawesi Barat, Sulawesi Tengah, dan Sulawesi Tenggara yang memiliki jarak tempuh terdekat dengan kota Makassar jika dibandingkan dengan subjek yang berasal dari pulau yang berbeda seperti Kalimantan, Jawa, Sumbawa, dan Sumatera. Subjek yang berasal dari daerah Sulawesi dianggap masih memiliki kesamaan nilai dengan nilai-nilai budaya Makassar yang membuat subjek mudah memahami nilai-nilai yang berlaku di Makassar.

Hasil penelitian ini mendukung penelitian sebelumnya mengenai keterkaitan antara motivasi, hubungan sosial, dan kinerja akademik. Wentzel (2017) menemukan bahwa kompetensi sosial dapat menjadi faktor yang menguatkan motivasi untuk belajar dan meningkatkan kinerja akademik. Pada budaya Indonesia yang cenderung kolektivistik, konteks interaksi sosial, norma, pandangan, dan harapan orang lain menjadi faktor yang memengaruhi tingkat motivasi individu (Markus, 2016; Trumbull \& Rothstein-Fisch, 2011). Individu tergerak untuk mencapai tujuannya apabila terjadi keseimbangan antara atribusi internal dirinya dengan pengaruh orang lain dan ekspektasinya terhadap individu tersebut (Markus, 2016).

$$
\text { Lebih lanjut, Solihatin }
$$
menjelaskan bahwa ciri-ciri tingginya motivasi belajar mahasiswa di antaranya adalah: (a) percaya diri akan kemampuan, (b) meraih hasil belajar di atas rata-rata, (c) tujuan belajar untuk kepuasan diri, (d) berusaha keras untuk sukses, (e) berupaya meraih hasil belajar yang tinggi, (f) berkelompok dengan teman yang pintar, (f) menyelesaikan tugas demi masa depan, (g) selalu mengerjakan tugas sendiri, (h) berusaha belajar walaupun lelah atau sakit, dan (i) kegigihan akan memengaruhi keberhasilan. Idealnya, mahasiswa perantau memiliki motivasi belajar yang tinggi dalam mencapai tujuan di lingkungan budaya yang baru. Mahasiswa perantau yang menunjukkan motivasi rendah harus dilihat dari faktor internal dan eksternalnya apakah sudah terbantu dalam hal media belajar, kondisi belajar, peraturan yang mendukung, prosedur kerja dengan alokasi waktu yang cukup, perbedaan kebiasaan, sikap, nilai, dan budaya. Budaya yang baru biasanya dapat menimbulkan tekanan karena memahami dan menerima nilai-nilai budaya lain adalah sesuatu yang sangat sulit, terlebih jika nilai-nilai budaya tersebut sangat berbeda dengan nilai-nilai budaya yang dimiliki (Kingsley \& Dakhari, 2006).

Kegagalan individu melakukan penyesuaian diri menyebabkan terjadinya disorientasi psikologis. Disorientasi psikologis 
yang dimaksudkan dalam penelitian ini adalah gegar budaya. Niam (2009) mengatakan bahwa gegar budaya adalah tekanan dan kecemasan yang dialami oleh individu ketika pergi ke suatu sosial dan budaya yang baru. Gegar budaya dapat terjadi dalam lingkungan yang berbeda, pada perpindahan dalam negaranya sendiri (intra-national) atau individu yang berpindah ke negera lain. Studi sebelumnya menunjukkan bahwa gegar budaya yang dirasakan oleh mahasiswa dapat memengaruhi emosi, sehingga mahasiswa merasa gagal dalam mencapai tujuan yang diharapkan saat studi di daerah lain (Hanson \& Dracos, 2016). Dampak negatif dari gegar budaya yaitu depresi, cemas, dan perasaan tidak berdaya yang akan menyebabkan terjadinya disorientasi psikologis yang lebih pada individu, sehingga individu kesulitan dalam mempelajari budaya baru (Ward et al., 2001). Disorientasi juga dapat memengaruhi kemampuan individu dalam memecahkan masalah dan mengambil keputusan dan hal ini akan menurunkan motivasi untuk beradaptasi dengan hal-hal yang baru (Xia, 2009). Zhou et al. (2008) mengemukakan bahwa untuk berhasil dalam menyelesaikan tugas-tugas di budaya baru, individu harus berinteraksi secara efektif dengan orang-orang lokal. Jika individu mengalami gegar budaya, maka perasaan negatif, frustasi dan ketidakmampuan untuk berperilaku tepat akan menghambat individu berinteraksi secara efektif dengan orang-orang lokal. Individu akan sering merasa terisolasi yang sebagian besar disebabkan karena kurangnya keterampilan komunikasi.

Hasil analisis gegar budaya dan motivasi belajar berada pada kategori sedang. Hasil temuan ini tidak sesuai dengan data awal peneliti yang melaporkan bahwa mahasiswa perantau mengalami gegar budaya dan memiliki motivasi belajar yang rendah. Hambatan dalam proses penelitian ini adalah sulitnya menemukan subjek yang sesuai dengan kriteria, yaitu subjek yang memiliki nilai yang berbeda dengan budaya Makassar, mengakibatkan sebaran pengambilan data tidak menyeluruh dalam lingkup Universitas X, sehingga hal tersebut memungkinkan kurang terungkapnya gambaran deskriptif tentang gegar budaya dan motivasi belajar pada mahasiswa perantau di Universitas X. Implikasi dari penelitian ini adalah dapat menjadi acuan bagi peneliti selanjutnya untuk mempertimbangkan faktor status sosioekonomi dan tipe kepribadian dalam kaitannya dengan gegar budaya dan motivasi belajar.

\section{Simpulan}

Ada hubungan negatif antara gegar budaya dan motivasi belajar mahasiswa perantau di Universitas X di Kota Makassar. Artinya, semakin tinggi gegar budaya yang dialami mahasiswa perantau, maka motivasi belajarnya semakin rendah.

\section{Saran}

Bagi peneliti lain yang berminat mengembangkan penelitian serupa, diharapkan 
dapat memperluas cakupan subjek penelitian. Peneliti juga dapat menggunakan metode kualitatif untuk mendapatkan dinamika psikologis perantau yang mengalami gegar budaya. Bagi mahasiswa, penelitian ini diharapkan menjadi informasi bahwa gegar budaya dapat menjadi hambatan yang melemahkan akademik. Oleh karena itu, disarankan untuk memperluas pertemanan dan interaksi, agar gegar budaya tidak menjadi beban yang menghambat pencapaian akademik dan perlu upaya dalam meningkatkan motivasi belajar secara intrinsik. Lembaga pendidikan atau dosen disarankan untuk menyediakan informasi mengenai budaya setempat pada masa orientasi mahasiswa baru, memberikan dukungan bagi mahasiswa perantau, memberikan kesempatan dalam berinteraksi melalui aktivitas kelompok dan upaya dalam memupuk kepercayaan diri mahasiswa perantau.

\section{Referensi}

Acharya, A., Prakash, A., Saxena, P., \& Nigam, A. (2013). Sampling: Why and how of it? Indian Journal of Medical Specilaities, 4(2), 330-333. https://doi.org/10.7713/ ijms.2013.0032

Agustin, M. (2009). Model konseling kognitif perilaku untuk menangani kejenuhan belajar mahasiswa (Studi pengembangan model konseling pada mahasiswa Universitas Pendidikan Indonesia tahun akademik 2008/2009). Universitas Pendidikan Indonesia.

Andriani NS, H. (2011). Hubungan motivasi belajar dan prestasi akademik mahasiswa SI Keperawatan Sekolah Tinggi Ilmu
Kesehatan Dian Husada Mojokerto.Jurnal Keperawatan, 1(1), 1-10.

Cai, D. A., \& Rodríguez, J. I. (1996). Adjusting to cultural differences: The intercultural adaptation model. Intercultural Communication Studies, 6(2), 31-42.

Choirunisa, N. L., \& Marheni, A. (2019). Perbedaan motivasi berpretasi dan dukungan sosial teman sebaya antara mahasiswa perantau dan non perantau di Fakultas Kedokteran Universitas Udayana. Jurnal Psikologi Udayana, 6(1), 21-30. https://doi.org/10.24843/ JPU.2019.v06.i01.p03

Choudhary, S. K. (2013). Social and cultural factors influence motivation Employees in a small town of Uttarakhand, India. IOSR Journal of Business and Management, 14(6), 6-14. https://doi.org/10.9790/487x-1460614

Djamarah, S. B. (2008). Psikologi belajar (2nd ed.). Rineka Cipta.

Ediana, L. T. P. J. (2009). Culture shock yang dialami mahasiswa perantauan FISIP UAJY angkatan 2008 dan pengaruhnya terhadap motivasi kuliah. Universitas Atma Jaya Yogyakarta.

Fariki, T. S. (2013). Penyesuaian kebudayaan di kampus Universitas Negeri Semarang. Universitas Negeri Semarang.

Field, A. (2009). Discovering statistics using SPSS (3rd Ed.). SAGE Publications.

Hanson, A. S., \& Dracos, M. (2016). Motivation and technology use during secondlanguage study abroad in the digital age. Canadian Journal of Applied Linguistics, 19(2), 64-84.

Iguisi, O. (2009). Motivation-related values across cultures. African Journal of Business Management, 3(4), 141-150.

Indrianie, E. (2012). Culture adjustment training untuk mengatasi culture shock pada mahasiswa baru yang berasal dari luar Jawa Barat. INSAN Media Psikologi, 14(3), 149-158. 
Isik, U., Tahir, O. El, Meeter, M., Heymans, M. W., Jansma, E. P., Croiset, G., \& Kusurkar, R. A. (2018). Factors influencing academic motivation of ethnic minority students: A review. SAGE Open, 8(2), 1-23. https:/ /doi.org/10.1177/2158244018785412

Kingsley, R. S., \& Dakhari, J. O. (2006). Culture shocked. Academic Press.

Kristini, R. E., \& Mere, F. N. (2010). Hubungan antara motivasi belajar dengan prestasi akademik pada mahasiswa Prodi Keperawatan S1 Program A Angkatan I Stikes RS. Baptis Kediri.Jurnal Penelitian Stikes RS Baptis Kediri, 3(1), 13-18.

Maciej, K., \& Katarzyna, K. (2018). Methods, tools and techniques for multimodal analysis of accommodation in intercultural communication. Computational Methods in Science and Technology, 24(1), 29-41. https:// doi.org/10.12921/cmst.2018.0000006

Maehr, M. L. (2008). Culture and achievement motivation. International Journal of Psychology, 43(5), 917-918. https:// doi.org/10.1080/00207590701838162

Markus, H. R. (2016). What moves people to action? Culture and motivation. Current Opinion in Psychology, 8, 161-166. https:/ /doi.org/10.1016/j.copsyc.2015.10.028

Maslow, A. H. (1943). A theory of human motivation. Psychological Review, 50(4), 370-396. https://doi.org/10.1037/ h0054346

Mubarok, A. F. (2012). Penyesuaian diri para pendatang di lingkungan baru. Journal of Social and Industrial Psychology, 1(1), 2127.

Mustajbašiæ, E., \& Husakoviæ, D. (2016). Impact of culture on work motivation: Case of Bosnia and Herzegovina. Journal of Business \& Economic Policy, 3(3), 7987.

Nadlyfah, A. K., \& Kustanti, E. R. (2018). Hubungan antara pengungkapan diri dengan penyesuaian diri pada mahasiswa rantau di Semarang. Empati, 7(1), 136144.

Niam, E. K. (2009). Koping terhadap stres pada mahasiswa luar Jawa yang mengalami culture shock di Universitas Muhammadiyah Surakarta. Indegenous: Jurnal Ilmiah Berkala Psikologi, 11(1), 69-77. https://doi.org/10.23917/ indigenous.v11i1.1615

Oberg, K. (1960). Cultural shock: Adjustment to new cultural environments. Practical Anthropology, os-7(4), 177-182. https:/ / d o i . o r g / 10 . 11177 / 009182966000700405

Primasari, W. (2014). Pengelolaan kecemasan dan ketidakpastian diri dalam berkomunikasi studi kasus mahasiswa perantau UNISMA Bekasi. Jurnal IImu Komunikasi, 12(1), 26-38.

Razzak, N. L. A. (2016). Cultural factors impacting student motivation at a health sciences college in the Eastern province of Saudi Arabia. Cogent Education, 3(1), 1153214. https://doi.org/10.1080/ 2331186X.2016.1153214

Rhein, D. (2018). International university students in Thailand: Shifting from universalistic models to an ethnicity matters approach. Journal of Research in International Education, 17(3), 286-308. h t tps://doi.org / 10.1177 / 1475240918817412

Ridha, A. A. (2014). Peran status sosioekonomi orangtua dan penyesuaian diri terhadap motivasi intrinsik dalam belajar. Jurnal Nalar Pendidikan, 2(1), 1-6. https:// doi.org/10.26858/jnp.v2i1.5923

Riezky, A. K., \& Sitompul, A. Z. (2017). Hubungan motivasi belajar dengan indeks prestasi kumulatif mahasiswa Program Studi Pendidikan Dokter Fakultas Kedokteran Universitas Abulyatama. Jurnal Aceh Medika, 1(2), 79-86.

Sardiman, A. M. (2009). Interaksi dan motivasi belajar mengajar. Rajawali Pers. 
Setiawan, R. (2010). Analisis pengaruh faktor kemampuan dosen, motivasi belajar ekstrinsik dan intrinsik mahasiswa, serta lingkungan belajar terhadap semangat belajar mahasiswa di departemen matakuliah umum Universitas Kristen Petra. Jurnal Ilmiah, 1, 229-244.

Solihatin, E. (2012). Upaya peningkatan motivasi belajar melalui dialog kreatif. Jurnal Ilmiah Mimbar Demokrasi, 11(2), 68-86. https://doi.org/10.21009/ jimd.v11i2.6258

Stoynoff, S. (1997). Factors associated with international students' academic achievement. Journal of Instructional Psychology, 24(1), 56-68.

Thariq, M., \& Anshori, A. (2017). Komunikasi adaptasi mahasiswa indekos. Jurnal Interaksi, 1(2), 156-173. https://doi.org/ 10.30596/interaksi.v1i2.1201

Trumbull, E., \& Rothstein-Fisch, C. (2011). The intersection of culture and achievement motivation. The School Community Journal, 21(2), 25-53.

Tuominen-Soini, H., \& Salmela-Aro, K. (2014). Schoolwork engagement and burnout among Finnish high school students and young adults: profiles, progressions, and educational outcomes. Developmental Psychology, 50(3), 649-662. https:// doi.org/10.1037/a0033898

Vincent T, V., \& Kumar, M. S. (2019). Motivation: Meaning, definition, nature of motivation. International Journal of Yogic, Human Movementand Sports Sciences, 4(1), 483-484.

Ward, C., Bochner, S., \& Furnham, A. (2001). The psychology of culture shock (2nd ed.). Routledge.
Wentzel, K. R. (2017). Peer relationships, motivation, and academic performance at school. In A. J. Elliot, C. S. Dweck, \& D. S. Yeager (Eds.), Handbook of competence and motivation: Theory and application (pp. 586-603). The Guilford Press.

Wijanarko, E., \& Syafiq, M. (2013). Studi fenomenologi pengalaman penyesuaian diri mahasiswa Papua di Surabaya. Jurnal Psikologi Teori Dan Terapan, 3(2), 79-92. https://doi.org/10.26740/ jptt.v3n2.p79-92

Xia, J. (2009). Analysis of impact of culture shock on individual psychology. International Journal of Psychological Studies, 1(2), 97-101. https://doi.org/ 10.5539/ijps.v1n2p97

Yang, Y., Zhang, Y., \& Sheldon, K. M. (2018). Self-determined motivation for studying abroad predicts lower culture shock and greater well-being among international students: The mediating role of basic psychological needs satisfaction. International Journal of Intercultural Relations, 63, 95-104. h t tps://doi.org/10.1016/ j.ijintrel.2017.10.005

Zhou, Y., Jindal-Snape, D., Topping, K., \& Todman, J. (2008). Theoretical models of culture shock and adaptation in international students in higher education. Studies in Higher Education, 33(1), 63-75. https://doi.org/10.1080/ 03075070701794833

Received 17 October 2019

Revised 18 April 2020 Accepted 30 May 2020 